\title{
FORMULASI KEBIJAKAN PEMBENTUKAN KURIKULUM MUATAN LOKAL BUDIDAYA DAN AGRIBISNIS JAGUNG
}

\author{
Lucky Dafira Nugroho \\ Fakultas Hukum Universitas Trunojoyo Madura \\ e-mail: lucky.dafira@trunojoyo.ac.id \\ Aprilina Pawestri \\ Fakultas Hukum Universitas Trunojoyo Madura \\ e-mail: aprilina.pawestri@trunojoyo.ac.id \\ Indah Setyo Wardhani \\ Fakultas Ilmu Pendidikan Universitas Trunojoyo Madura \\ e-mail: indahsetyo.wardani@trunojoyo.ac.id \\ disampaikan 31/08/2019 - di-review 19/11/2011 - diterima 03/12/2020 \\ DOI: $10.25123 /$ vej.3473
}

\begin{abstract}
This article addressed the question, from a juridical empirical approach) to what extent the making and implementation of a new curriculum at formal educational institution at Madura containing lesson for the preservation and development of local corn cultivation and agriculture may have positive impact on the enhancement of the local economy. Field study is conducted at the Sumenep district. The main finding is that the regional autonomy policy opens up the possibility for regional/local government to make and implement educational policy introducing a new curriculum containing lesson in local corn cultivation and corn agribusiness. This new curriculum may be implemented at the basic school up to the intermediate level with the purpose of strengthening local culture, i.e., traditional corn cultivation. With that in mind a regional regulation should be issued providing the legal basis for the above policy.
\end{abstract}

Keywords: Educational Policy, Traditional Corn Cultivation, Agribusines

\begin{abstract}
Abstrak
Tulisan ini, dengan menggunakan pendekatan yuridisi empiris, menelaah persoalan sejauh mana pembentukan kurikulum muatan lokal berupa pembelajaran budidaya dan agribisnis jagung dapat melestarikan dan meningkatkan potensi lokal Madura. Studi lapang dilakukan di Kabupaten Sumenep. Kesimpulan yang diperoleh adalah adanya otonomi daerah membuka peluang bagi pemerintah daerah untuk merumuskan kebijakan daerah di bidang pendidikan dan perumusan kurikulum di tingkat sekolah dasar dan sekolah menengah pertama yang memuat tujuan penguatan ciri khas kedaerahan dan pelestarian potensi lokal yang ada berupa jagung di Kabupaten Sumenep. Peluang inilah yang harus dimanfaatkan dengan membuat payung hukum: peraturan daerah yang dapat mendorong pembuatan kurikulum yang memberikan perhatian pada muatan lokal budidaya dan agribisnis Jagung Madura.
\end{abstract}

Kata Kunci:

Kebijakan, Muatan Lokal, Budidaya, Agribisnis, Jagung 


\section{Pendahuluan}

Pemberian otonomi kepada daerah melalui asas desentralisasi ${ }^{1}$ akan mendorong lebih banyak peran serta pemerintah daerah dalam memenuhi kebutuhannya dibandingkan dengan pemerintah pusat, karena esensi pemerintah daerah berkaitan erat dengan kewenangan yang dimilikinya dalam mengurus dan mengatur urusan rumah tangga pemerintahannya. ${ }^{2}$ Sebagaimana yang dijelaskan oleh Ni'Matul Huda, sistem desentralisasi mengandung makna pengakuan penentu kebijaksanaan pemerintah terhadap potensi dan kemampuan daerah dengan melibatkan wakil - wakil rakyat di daerah dalam menyelenggarakan pemerintahan dan pembangunan, dengan melatih diri menggunakan hak yang seimbang dengan kewajiban masyarakat yang demokratis. ${ }^{3}$

Penerapan asas desentralisasi berbeda dengan asas sentralistik, yang menitik beratkan pada kewenangan kekuasaan pemerintahan pusat. Dengan berlakunya asas desentralisasi daerah dapat mengelola semua potensi yang ada di wilayahnya, mulai sumber daya manusia, sumber daya alam dan lain sebagainya. Setiap daerah di Indonesia memiliki potensi yang berbeda-beda sebagai contoh adalah potensi Provinsi Bali dengan wisatanya dan Nusa Tenggara Barat dengan wisata syariahnya.

Potensi lokal tersebut akan mendukung kesejahteraan masyarakat lokal secara khusus dan masyarakat Indonesia secara umum. Pengelolaan potensi dan kekhasan daerah ini sangat bergantung pada pemerintah daerah masing-masing. Salah satu potensi yang berkaitan dengan kebutuhan pokok manusia adalah di bidang pangan. Tidak semua daerah di Indonesia telah mampu berswasembada pangan. Potensi produk pangan yang perlu untuk di dorong menuju swasembada

1 Desentralisasi secara entimologis berarti "de" = lepas dan "centrum" = pusat sehingga berdasarkan peristilahannya desentralisasi adalah melepaskan diri dari pusat. Lihat RDH Koesoemaatmadja, Pengantar ke Arah Sistem Pemerintahan Daerah di Indonesia, Bina Cipta, Bandung, 1979, hlm., 14.

2 Sirojul Munir dalam Roni Rustandi, Kajian Teoritis Fungsi Pemerintah Daerah Dan Dewan Perwakilan Rakyat Daerah Dalam Pembentukan Peraturan Daerah Menurut Undang - Undang Nomor 23 Tahun 2014 tentang Pemerintahan Daerah Sebagaimana Telah Diubah Dengan Undang-Undang Nomor 9 Tahun 2015, Jurnal Surya Kencana Dua : Dinamika Masalah Hukum dan Keadilan, Volume 4, Nomor 1 Juli 2017, hlm., 37

3 Ni'Matul Huda, Otonomi Daerah, Filosof, Sejarah Perkembangan dan Problematika, Pustaka Pelajar, Yogyakarta, 2005, hlm., 85. 
antara lain padi, jagung, kedelai, dll. Walaupun suatu daerah tersebut memiliki lahan untuk dijadikan lahan pertanian, tetapi belum tentu dapat mengelola dengan baik. Salah satu nya yang menjadi fokus penelitian ini, yaitu di Kabupaten Sumenep. Yang juga di buktikan dengan melakukan survei awal ke beberapa putra-putri petani khususnya yang orang tuanya berprofesi sebagai petani jagung. Mereka menyatakan keengganannya untuk mengikuti jejak orang tuanya sebagai petani dengan alasan keinginan untuk memperoleh penghidupan yang lebih baik karena menjadi petani jagung kurang membawa kesejahteraan.

Selain dikenal dengan pulau garam dan penghasil daging sapi, pulau Madura juga dikenal sebagai penghasil jagung terutama sumber daya genetik lokal jagung madura. Terutama setelah tahun 2016, Pemerintah Republik Indonesia telah menerapkan pembatasan impor jagung dan mendorong peningkatan produksi jagung nasional.

Jika melihat dari sejarah masyarakatnya, jagung tidak bisa dilepaskan dari masyarakat Madura karena jagung merupakan makanan pokok masyarakat Madura dan tanaman ini merupakan salah satu komoditas yang banyak dibudidayakan oleh petani Madura. ${ }^{4}$ Namun, keinginan dan target pemerintah ini tentunya bukan suatu hal yang mudah untuk diwujudkan. Mengingat keterbatasan dana, luas lahan dan kemauan petani untuk menanam jagung. Jika melihat era yang semakin maju ini, tidak banyak masyarakat yang tetap konsisten menjadi petani atau bahkan buruh tani. ${ }^{5}$ Jagung yang masih banyak di tanam oleh masyarakat adalah jagung lokal Madura, bukan jagung sesuai dengan anjuran pemerintah.

4 Dikutip dari http://www.teropongmadura.net/2016/12/jagung-madura.html. dan diakses pada 21 Juli 2018

5 Selain itu permasalahan pokok rendahnya produksi jagung ditingkat petani tersebut disebabkan oleh kurang suburnya lahan, curah hujan yang cenderung rendah dan sebagian besar benih yang digunakan bukan hasil dari program pemuliaan (baik melalui seleksi atau hibridisasi). Lihat dalam http://www.teropongmadura.net/2016/12/jagung-madura.html. diakses pada 21 Juli 2018. 
Alasan penanaman jagung lokal Madura antara lain:

1. Mempunyai daya simpan yang lama (kurang lebih 1 tahun) sehingga dapat digunakan sebagai cadangan makanan selama satu tahun.

2. Jagung lokal Madura memiliki kandungan protein dan lemak tinggi masingmasing 11,24 \% dan 4,96 \% dibanding jagung-jagung hibrida seperti Pioneer 7 (kandungan protein 8,22 \% dan kandungan lemak 3,24 \%), Pioneer 11 (kandungan protein 8,70 \% dan kandungan lemak 3,34\%), Bisi 2 (kandungan protein 9,51 \% dan kandungan lemak 3,95\%) dan Bisi 7 (kandungan protein 10,09\% dan kandungan lemak 3,27 \%). ${ }^{6}$

Kelemahan dari jagung lokal Madura adalah produksi per hektar paling rendah dibandingkan daerah penghasil jagung lainnya di Jawa Timur. Dengan hasil yang rendah seperti ini perlu dilakukan evaluasi terkait dengan penanaman jagung di Madura karena ada perbedaan lahan dan hasil jagung dari setiap Kabupaten di pulau Madura.

Hal yang perlu dievalusi tidak hanya di tingkat kemauan petani dalam menanam jagung sesuai anjuran pemerintah dan perlu memperhatikan ciri atau kekhasan Madura itu sendiri. Belum tentu apa yang ada dalam tataran pusat akan berjalan baik jika di terapkan di daerah. Edukasi terhadap pentingnya penggunaan lahan pertanian tidak hanya kepada petani, namun juga kepada anak-anak petani atau masyarakat umumnya bahkan dimulai ketika mereka masih kecil. Masih duduk di bangku sekolah. Dengan kata lain mensinkronkan potensi daerah dengan materi bermuatan lokal di daerah masing-masing.

Walaupun hasil tidak dapat secara instan dirasakan, tetapi agar setiap daerah dapat berkembang sesuai dengan potensinya, merencanakan kurikulum pendidikan berbasis potensi daerah merupakan sebuah keniscayaan. ${ }^{7}$ Terutama jika dapat dimasukkan dalam kurikulum Sekolah Menengah Kejuruan yang

6 Hasil penelitian Suhardjo dan Lestari http://www.teropongmadura.net/2016/12/jagungmadura.html. diakses 21 Juli 2018

7 Diera mendikbud Anes Baswedan kebijakan ini pernah dilakukan. Dalam hal ini langkah yang diambil oleh pemerintah pusat dengan memperhatikan kondisi lokal dalam proses penyususnan kurikulum baru merupakan kebijakan yang tepat. Dikutip dari https://www.kompasiana.com/ramdan69/kurikulum-pendidikan-berbasis-potensidaerah_559489027293739413cb192e. diakses 19 Juli 2018. 
tujuannya setelah lulus dapat langsung mengaplikasikannya/menerapkannya. Memasukkan potensi lokal dalam kurikulum juga lebih mampu memberikan pemahaman tentang kekhasan masing-masing daerah kepada masyarakatnya khususnya kepada anak didik.

Saat ini potensi lokal daerah yang diperkenalkan dalam kurikulum baru sebatas pengetahuan tentang bahasa daerah maupun seni budaya setempat. Padahal potensi yang dimiliki oleh setiap daerah sebenarnya lebih dari itu. Potensi dibidang pertanian, pertambangan serta pariwisata sejatinya merupakan modal dasar yang sangat berharga untuk kemudian dikembangkan agar mendatangkan manfaat bagi masyarakat sekitar. Dalam hal ini dunia pendidikan berperan penting dalam menyiapkan SDM yang mampu membangun daerahnya. ${ }^{8}$ Jika dikaitkan dengan potensi lokal Madura, memasukkan kurikulum dengan muatan lokal Madura tidak hanya dibidang bahasa Madura, seni budaya Madura (tari, lagu, adat istiadat), tetapi juga potensi di bidang pertanian (jagung, tembakau, garam) dan bidang peternakan (sapi), serta masih banyak lagi potensi yang sejatinya bisa di masukkan dalam kurikulum lokal. Adapun yang dimaksud dengan kurikulum lokal ini adalah kurikulum muatan lokal yang merupakan "kegiatan kurikuler yang bertujuan untuk mengembangkan kompetensi yang disesuaikan dengan ciri khas dan potensi daerah, yang materinya tidak dapat dikelompokkan dalam mata pelajaran yang ada". ${ }^{9}$ Dengan kata lain substansi muatan lokal disesuaikan dengan potensi dan ciri khas daerah masing-masing.

Dalam penyelenggaraan pendidikanpun mengsyaratkan pentingnya muatan lokal kedaerahan terdapat dalam Undang-Undang Nomor 20 Tahun 2003 tentang Sistem Pendidikan Nasional antara lain berisi pesan bahwa kurikulum memperhatikan keragaman potensi daerah dan lingkungan (Pasal 36, ayat (3)

8 https://www.kompasiana.com/ramdan69/kurikulum-pendidikan-berbasis-potensidaerah_559489027293739413cb192e. diakses 19 Juli 2018.

9 Departemen Pendidikan Nasional, Model Mata Pelajaran Muatan Lokal SD/MI/SDLBSMP/MTs/ SMPLB-MA/MA/SMALB/SMK.Jakarta: Balitbang Depdiknas, 2006, hlm. 5. dikutip dari Al Musanna, Revitalisasi Kurikulum Muatan Lokal Untuk Pendidikan Karakter Melalui Evaluasi Responsif, Jurnal Pendidikan dan Kebudayaan, Vol. 16, Edisi Khusus III, Oktober 2010, hlm., 246. 
huruf d). Pada bagian lain terdapat pesan bahwa kurikulum pendidikan dasar dan menengah wajib memuat muatan lokal (Pasal 37 ayat (1) huruf j). Sejumlah manfaat dapat diperoleh dengan menyelaraskan potensi lokal daerah khususnya Madura dalam kurikulum di sekolah:

1. Bagi daerah, dapat berfungsi sebagai pelestari potensi daerah sekaligus mendatangkan manfaat ekonomi. Meskipun ini baru di dapat ketika siswa tersebut lulus.

2. Sedangkan bagi siswa, dapat menjadi bekal untuk berkarya setelah menyelesaikan pendidikan. Bekal dalam melihat dan mencari peluang dari potensi yang ada.

Salah satu contoh yang berhasil adalah pengenalan potensi lokal, yaitu pada kurikulum di daerah Nusa Tenggara Timur (NTT) dengan potensi kayu cendana. Kayu cendana itu sempat mengharumkan pulau timur karena manfaat dan keharumannya, bahkan sampai di ekspor keluar negeri. Namun, saat ini kayu cendana nyaris punah. Hal penting yang dilakukan oleh pemerintah setempat adalah melakukan pengenalan terhadap kayu cendana di mulai dari tingkat SD hingga SMA/SMK pada pendidikan formal. Dengan kurikulum muatan lokal, tanaman khas daerah ini dapat dilestarikan, bahkan dikembangkan menjadi produk bernilai ekonomi. Demikian juga dengan potensi pertanian, peternakan, pertambangan, bahkan potensi budaya, seperti kain tenun. ${ }^{10}$

Hal yang sama sangat dimungkinkan jika diterapkan di Madura, dengan melihat potensi jagung yang menjadi komoditi utama bahan pokok, khususnya jagung lokal Madura. Materi mengenai pengembangan potensi jangung lokal madura tersebut dimasukkan dalam kurikulum sekolah, dari sekolah dasar hingga SMA/SMK. Kurikulum muatan lokal ini ditata sedemikian rupa sehingga bersifat holistik, dimulai dari hulu hingga hilir. Dalam bahasa ekonomi, dimulai dari proses produksi sampai pemasaran sehingga menjadi petani jagung bukan hanya tentang menggarap lahan, tetapi juga bagaimana melakukan penamanan yang dapat menghasilkan hingga bagaimana jagung tersebut dapat di pasarkan maupun

10 http://kupang.tribunnews.com/2016/07/20/kurikulum-muatan-lokal-dan-potensi-daerah, diakses 18 Juli 2018. 
digunakan dalam memenuhi kebutuhan pokok sendiri sehingga target pemerintah swasembada pangan khususnya jagung di Madura bukan sesuatu hal yang sulit di capai.

Political Will pemerintah setempat sangat diharapkan, bersinergi dengan Dinas Pendidikan, dalam melakukan evaluasi dan penataan ulang kurikulum. Yang mampu mengetahui potensi daerah tentunya warga daerah itu sendiri sehingga setiap daerah dapat menetapkan peraturan daerah tentang potensi lokal di integrasikan dalam kurikulum pendidikan sekolah dasar hingga SMA/SMK.

Penelitian ini merupakan penelitian empiris yang mengkaji gejala dan realitas sosial di masyarakat. Penelitian ini menempatkan sebagai perposisi umum atau premis mayor. Gejala dan realitas sosial tersebut dicari melalui proses searching and researching atau pola-pola hubungan antara berbagai gejala yang memanifestasikan hadirnya hukum di dalam kenyataan, sebagaimana yang biasa disimak oleh indera pengamatan. ${ }^{11}$

Tahapan penelitian diawali dengan menegaskan masalah dengan cara merumuskannya ke dalam kalimat-kalimat interogatif, menduga jawaban secara spekulatif atas masalah yang diajukan, dan mencari bahan uji untuk melakukan verifikasi kebenaran baik dengan pengumpulan data dilapangan seperti wawancara narasumber baik khususnya Dinas Pendidikan Kabupaten Sumenep dan Dinas Pendidikan provinsi Jawa Timur sebagai penyelenggara pendidikan tingkat SMA dan SMK. Dinas Pertanian, Tanaman Pangan dan Hortikultura Kabupaten Sumenep dan Dinas Pertanian Provinsi Jawa Timur. Jika data yang terkumpul cukup, dilakukan analisis data, hingga diperoleh hasil penelitian.

Data primer adalah sejumlah data yang berupa keterangan atau penjelasan dari subjek penelitian, guna mendapakan penejlasan yang lebih mendalam tentang data sekunder. Data diperoleh dari hasil wawancara seperti, sejauhmana kebijakan daerah dalam sektor pendidikan untuk mengembangkan kearifan lokal madura berupa jagung madura dan karakteristik kurikulum mata pelajaran muatan lokal pelatihan budidaya dan agribisnis jagung madura yang tepat untuk

11 Hartiwiningsih dalam hartiwiningsih, Lego Karjoko dan Soehartono, Metode Penelitian Hukum, Universitas Terbuka, Banten, 2019, Kegiatan Belajar 3, modul 1.34. 
pendidikan dasar, menengah pertama, dan menengah atas tersebut merupakan sumber data primer yang dengan tetep berkordinasi dengan Dinas pertanian serta melakukan wawancara mendalam terhadap beberapa petani jagung.

Data sekunder meliputi data yang berupa dokumen-dokumen, tulisan, buku ilmiah dan literatur yang mendukung. Data yang demikian dapat berupa peraturan perundang-undangan, data statistik kabupaten Sumenep. Data yang di inginkan seperti data kurikulum pendidikan dasar, menengah pertama, dan menengah atas di lingkup madura dan provinsi Jawa Timur.

\section{Pembahasan}

\section{Kondisi Pertanian Jagung di Kabupaten Sumenep}

Jagung menjadi salah satu komoditi pertanian paling menonjol di Madura khususnya di Sumenep. Luas area pertanian di Sumenep mencapai 141 ribu Ha yang terbagi pada 27 kecamatan. Jagung selain menjadi makanan pokok masyarakat Madura, tetapi juga digunakan sebagai pakan ternak. Selama ini jagung yang dibudidayakan adalah jagung lokal Madura dan hanya sedikit yang kemudian dijual. Hal ini dipengaruhi oleh pola pikir masyarakat Sumenep dalam menanam jagung, yaitu tanam-pangan bukan tanam bisnis sehingga menanam jagung tidak memberikan nilai ekonomis. ${ }^{12}$ Hal ini sejalan dengan yang disampaikan oleh Bagas Praptomo selaku Kepala Bidang Pengelolaan dan Pemasaran pada Dinas Pertanian, Tanaman Pangan, dan Holtikultura Kabupaten Sumenep. Namun, karena kebutuhan jagung nasional yang harus dipenuhi masyarakat diminta untuk tidak hanya menanam jagung lokal, tetapi juga jagung hibrida. Produksi jagung lokal sebagai salah satu upaya mempertahankan kekhasan daerah di bidang pertanian unggulan. Namun, menanam jagung hibrida sebagai kebutuhan pasar dan memiliki nilai ekonomis yang lebih tinggi jika di bandingkan dengan jagung lokal.

Langkah yang dilakukan oleh Dinas Pertanian, Tanaman Pangan, dan Holtikultura Kabupaten Sumenep yaitu mengubah posisi tanaman antara jagung

12 Wawancara dengan Bagas Praptomo selaku Kepala Bidang Pengelolaan dan Pemasaran pada Dinas Pertanian, Tanaman Pangan, dan Holtikultura Kabupaten Sumenep pada 10 Agustus 2018 di Kantor Dinas Pertanian, Tanaman Pangan, dan Holtikultura Kabupaten Sumenep. 
lokal dengan jagung hibrida dengan perbandingan 70\% berbanding 30\% dan diarahkan untuk saat terbalik yaitu luas area untuk menanam jagung hibrida 70\% sisanya 30\% untuk ditanami jagung lokal. Kebijakan ini dilakukan untuk memenuhi kebutuhan jagung sebagai upaya untuk meningkatkan kesejahteraan para petani jagung Sumenep.

Data Dinas Pertanian, Tanaman Pangan, dan Holtikultura Kabupaten Sumenep mencatat di tahun 2017 terjadi perbedaan hasil yang signifikan antara petani menanam jagung lokal dan jagung hibrida. Sebagaimana dalam tabel di bawah ini:

Tabel 1: Perhitungan Hasil Tanam Jagung Hibrida dan Lokal Madura

\begin{tabular}{cccccccc}
\hline No & Jenis & $\begin{array}{c}\text { Luas } \\
\text { (Ha) }\end{array}$ & $\begin{array}{c}\text { Biaya per } \\
\text { Ha (Rp) }\end{array}$ & $\begin{array}{c}\text { Total } \\
\text { produksi } \\
\text { (kg) }\end{array}$ & $\begin{array}{c}\text { Harga } \\
\text { satuan } \\
\text { (Rp) }\end{array}$ & $\begin{array}{c}\text { Nilai total } \\
\text { produksi }\end{array}$ & $\begin{array}{c}\text { Keuntungan } \\
\text { tani/usaha } \\
\text { tani (Rp) }\end{array}$ \\
\hline 1 & $\begin{array}{c}\text { Jagung } \\
\text { lokal }\end{array}$ & 1 & 6.930 .000 & 2.200 & 3.500 & 7.700 .000 & 770.000 \\
\hline 2 & $\begin{array}{c}\text { Jagung } \\
\text { hibrida }\end{array}$ & 1 & 8.700 .000 & 6.800 & 3.300 & 22.110 .000 & 13.410 .000 \\
\hline
\end{tabular}

Sumber : Dinas Pertanian, Tanaman Pangan, Hortikultura, dan Perkebunan Kabupaten Sumenep

Dari data tersebut dapat dilihat bahwa keuntungan yang diperoleh petani lebih banyak jika menanam jagung jenis hibrida bila dibandingkan dengan jagung lokal. Meskipun jagung lokal juga memiliki beberapa keunggulan sebagaimana yang diutarakan oleh Bagas Praptomo antara lain jagung Madura memiliki masa simpan yang relatif lama dan lebih tahan terhadap hama, dan memiliki rasa yang lebih enak jika dibandingkan dengan jagung hibrida.

Meskipun demikian tidak mudah untuk mengubah pola masyarakat Sumenep agar mau mengganti tanam jagung lokal menjadi hibrida. Hal tersebut merupakan salah satu hambatan yang dirasakan oleh Dinas Pertanian, Tanaman Pangan, Hortikultura, dan Perkebunan Kabupaten Sumenep. Hambatan lainnya adalah banyaknya alih fungsi lahan pertanian menjadi lahan tidak produktif. Menurunnya jumlah petani jagung terutama generasi yang meneruskan tidak ada, sekalipun memiliki lahan pertanian. Selain itu banyak lahan pertanian yang digunakan untuk menanam tanaman selain jagung. 
Keadaan ini sesuai dengan pendapat para petani jagung, yang sebagian besar tidak menginginkan anak-anak mereka untuk bertani jagung. Dari enam (6) petani jagung di Desa Bungbungan, Kecamatan Bluto, Kabupaten Sumenep hanya satu (1) yang dengan tegas menginginkan anaknya meneruskan menjadi petani jagung. Sedangkan lima (5) lainnya menilai bahwa menjadi petani jagung hanya bisa untuk mencukupi kebutuhan sehari-hari. Salah satu responden bernama Amsito menuturkan, bahwa bertani jagung tidak mampu membiayai kebutuhan hidup. Ia harus memiliki pekerjaan sampingan untuk menopang kebutuhan hidupnya sehingga sangat dimungkinkan dikemudian hari lahan pertanian jagung tidak digunakan untuk menanam jagung atau bahkan menjadi lahan tidak produktif karena berkurangnya para petani jagung. ${ }^{13}$ Apalagi pemahaman menjadi petani adalah mereka yang menanam, memupuk, dan mengairi di sawah.

Perlu adanya sinergitas dari pemerintah Kabupaten Sumenep khususnya, untuk dapat mempertahankan dan juga meningkatan produktivitas pertanian jagung. Menurut Bagas Praptomo, langkah yang telah diambil untuk mempertahankan atau bahkan meningkatkan produktivitas petani jagung salah satunya membangun mitra dengan perbankan, bermitra dengan produsen benih dalam penyediaan benih khususnya bagi jagung hibrida. ${ }^{14}$ Terkait dengan alih fungsi lahan pertanian telah dibentuk PERDA Kabupaten Sumenep tentang LP2B atau Lahan Pangan Pertanian Berkelanjutan, yang kurang lebih berisi tentang batasan areal pertanian yang boleh dialih fungsikan. Ini perlu diambil untuk mempertahankan lahan sesuai dengan fungsinya semula.

Selain memiliki nilai jual berupa jagung kering (jagung pipil), pengolahan terhadap jagung juga di upayakan oleh Dinas Pertanian, Tanaman Pangan, Holtikultura, dan Perkebunan Kabupaten Sumenep adalah diversifikasi produk pertanian menjadi barang olahan asli Sumenep dengan bahan baku jagung, yaitu mie jagung, snack jagung, stik jagung, dan kripik jagung. Meskipun olahan jagung

13 Wawancara dengan Amsito yang merupakan warga Desa Bungbungan, Kecamatan Bluto, Kabupaten Sumenep. Pada tanggal 5 Juni 2018 di rumah Amsito.

14 Wawancara dengan Bagas Praptomo selaku Kepala Bidang Pengelolaan dan Pemasaran pada Dinas Pertanian, Tanaman Pangan, dan Holtikultura Kabupaten Sumenep pada 10 Agustus 2018 di Kantor Dinas Pertanian, Tanaman Pangan, dan Holtikultura Kabupaten Sumenep. 
ini juga memiliki hambatan ketika akan dipasarkan. Problematika perijinan produk serta lokasi pemasaran. Hambatan tersebut cukup menganggu dalam pencapaian target swasembada jagung di Kabupetan Sumenep. Hal yang lainnya adalah pada petani yang jumlahnya berangsur berkurang.

\section{Kurikulum Muatan Lokal di Kabupaten Sumenep}

Sebelum memasuki pembahasan formulasi kebaijakan terkait dengan pembentukan Kurikulum Muatan Lokal Budidaya Dan Agribisnis Jagung, perlu untuk di bahas mengapa menjadi penting sebuah kebijakan khususnya dalam mendukung sebuah kemajuan. Menurut Carl Fiedrich, memandang "kebijakan sebagai suatu arah tindakan yang diusulkan oleh seseorang, kelompok, atau pemerintah dalam suatu lingkungan tertentu, yang memberikan hambatanhambatan dan kesempatan-kesempatan terhadap kebijakan yang diusulkan untuk menggunakan dan mengatasi dalam rangka mencapai suatu tujuan, atau merealisasikan suatu sarana atau maksud tertentu".15 Dengan demikian dapat diambil kesimpulan bahwa kebijakan atau yang bisa di maksud dengan kebijakan publik adalah arah yang diusulkan untuk mengatasi suatu masalah agar mencapai tujuan dan merealisasikan suatu sarana dan maksud tertentu. Dalam hal ini kebijakan yang dimaksud adalah dimungkinkannya memasukkan muatan lokal budidaya dan agribisnis jagung. Untuk mendukung terlaksananya kebijakan ini, ada beberapa tahap penyusunan kebijakan publik yang perlu dilalui sebagaimana yang dijelaskan oleh James E Anderson adalah sebagai berikut:

a. Formulasi masalah (problem formulation): Apa masalahnya? Apa yang membuat hal tersebut menjadi masalah kebijakan? Bagaimana masalah tersebut dapat masuk dalam agenda pemerintah?

b. Formulasi kebijakan (formulation): Bagaimana mengembangkan pilihan-pilihan atau alternatif-alternatif untuk memecahkan masalah tersebut? Siapa saja yang yang berpartisipasi dalam formulasi kebijakan?

c. Penentuan kebijakan (adoption): Bagaimana alternatif ditetapkan? Persyaratan atau kriteria seperti apa yang harus dipenuhi? Bagaimana proses atau strategi untuk melaksanakan kebijakan yang ditetapkan?

15 Budi Winarno, Kebijakan Publik Teori dan Proses, ctk. Ketiga, Media Pressindo, Yogyakarta, 2005, hlm., 16. 
d. Implementasi kebijakan (implementation): Siapa yang terlibat dalam implementasi kebijakan? Apa dampak dari isi kebijakan?

e. Evaluasi (evaluation): Bagaimana tingkat keberhasilan atau dampak kebijakan diukur? Siapa yang mengevaluasi kebijakan? Apa konsekuensi dari adanya evaluasi kebijakan? Adakah tuntutan untuk melakukan perubahan atau pembatalan?.16

Bila dikaitkan dengan sistem pendidikan nasional, sebenarnya proses panjang perjalanan sebelum membuat kebijakan publik termasuk masalah pendidikan harus memperhatikan tahap-tahap dalam proses pembuatan kebijakan publik. ${ }^{17}$ Dalam hal ini terkait dengan penetapan kurikulum, sedangkan dalam penelitian ini menitikberatkan pada tahap formulasi kebijakan. Setelah diketahui masalahnya, yaitu bahwa salah satu hal yang mendukung kurangnya pelestarian jagung lokal Madura khususnya di Sumenep adalah siswa yang kurang mengenal potensi lokal daerahnya yaitu jagung lokal Madura sehingga diperlukan sebuah formulasi kebijakan sebagai bentuk pengembangan pilihan atau alternatif untuk memecahkan masalah agar potensi lokal jagung Madura ini terus mampu dilestarikan, serta pihak-pihak yang nantinya mendukung serta berpartisipasi dalam formulasi kebijakan ini.

Untuk kemudian mendukung penelitian ini Formulasi Kebijakan Pembentukan Kurikulum Muatan Lokal Budidaya Dan Agribisnis Jagung telah dilakukan pengumpulan data yang tersebar di beberapa tempat, yang tentunya mendukung hasil penelitian.

1. Dinas Pendidikan Provinsi Jawa Timur untuk mengetahui kebijakan Provinsi terkait penerapan muatan lokal di tingkat SMK khususnya.

2. Dinas Pendidikan Kabupaten Sumenep untuk mengetahui muatan lokal apa saja yang di peroleh siswa baik di tingkat sekolah dasar (SD/Sederajat) dan menengah pertama (SMP/Sederajat).

16 James Anderson dalam Subarsono, Analisis Kebijakan PublikI Konsep, Teori dan Aplikasi, Pustaka Pelajar, Yogyakarta, 2006, hlm., 12-13.

17 Ratna Dewi, Kebijakan Pendidikan Di Tinjau Dari Segi Hukum Kebijakan Publik, Jurnal Ilmu Hukum, Volume 7, Nomor 2, Oktober, 2016, hlm., 60. 
3. Dinas Pertanian dan Ketahanan Pangan Provinsi Jawa Timur, terkait dengan potensi lokal yang di miliki Jawa Timur khususnya Jagung sesuai topik penelitian.

4. Dinas Pertanian, Tanaman Pangan, Hortikultura, dan Perkebunan Kabupaten Sumenep terkait dengan produksi jagung sumenep, kendala, tantangan dan mengembangkan jagung baik jagung lokal madura maupun jagung hibrida.

5. Wawancara dengan beberapa petani jagung di Sumenep.

Kurikulum menjadi penting dalam dunia pendidikan. Kurikulum merupakan sebuah dokumen perencanaan yang berisi tentang tujuan yang harus dicapai, isi materi, dan pengalaman belajar yang berisi tentang tujuan yang harus dilakukan siswa, strategi, dan cara yang dapat dikembangkan. Evaluasi yang dirancang untuk mengumpulkan informasi tentang pencapaian tujuan serta implementasi dari dokumen yang dirancang dalam bentuk nyata. Dengan demikian, pengembangan kurikulum meliputi penyusunan dokumen serta evaluasi dokumen yang telah disusun. ${ }^{19}$

Kurikulum juga akan mempengaruhi keahlian atau kemampuan siswa ketika mereka lulus dan memsuki dunia kerja. Dalam penyusunan kurikulumpun perlu memperhatikan berbagai macam aspek sehingga tidak ayal jika penerapan kurikulum bisa berganti beberapa kali. Sejak diterapkannya otonomi daerah dengan sistem desentralisasi pada masa reformasi menjadikan daerah-daerah otonom di Indonesia memiliki sejumlah kewenangan dalam bidang pendidikan. Kebijakan desentralisasi bidang pendidikan di Indonesia tidak berbeda dengan tujuan umum sistem desentralisasi itu sendiri yang berorientasi pada pelibatan masyarakat dan sekolah serta pemerintah daerah dalam pengelolaan pendidikaan semakin berkualitas. ${ }^{18}$

Hal ini sejalan dengan apa yang ada dalam Undang-Undang Nomor 23 tahun 2014 tentang Pemerintahan Daerah pada BAB IV terkait Urusan Pemerintahan, yang secara tegas garis besar menyatakan bahwa Pendidikan

18 Suwandi dalam Sufriadi dan Sobirin Malian, Problem Kewenangan Pemerintah Daerah Dalam Pengelolaan Perguruan Tinggi, Jurnal Yudisial, Volume 12, Nomor 3, Desember, 2019, hlm., 306. 
menjadi salah satu urusan pemerintahan wajib terkait dengan pelayanan dasar (Pasal 12 ayat 1, huruf a), dimana pelaksanaannya dibagi antara pemerimtah pusat, daerah provinsi serta daerah kabupaten/kota. ${ }^{19}$

Adanya pembagian urusan ini memberikan keuntungan bagi daerah, dimana daerah diberikan keleluasaan dalam pengelolaan pendidikan. Kabupaten atau Kota memiliki tanggung jawab dalam pengelolaan pendidikan dasar (SDSMP). Sedangkan Provinsi memiliki tanggung jawab dalam penyelenggaraan pendidikan tingkat atas (SMA/SMK). Kondisi ini sangat memungkinkan bagi daerah mengkolaborasikan mata pelajaran-mata pelajaran khususnya yang masuk kategori muatan lokal dengan kekhasan daerah. Yang pada akhirnya bisa menunjang dunia pendidikan maupun mendukung potensi daerah masing-masing.

Muatan lokal inipun akan berbeda tentunya pada masing-masing daerah tergantung pada potensi lokal daerah tersebut. Yang dapat dijadikan materi muatan lokal seperti seni budaya, ketrampilan atau potensi lain di bidang pertanian, perkebunan, dan kelautan. Karakteristiknya harus menunjukkan ciri khas suatu daerah. Madura yang memiliki julukan sebagai "pulau garam" pun tidak hanya memiliki potensi lokal garam, masih terdapat sapi, gas bumi, pariwisata dengan pantainya, jagung serta tembakau pada sektor pertanian. Potensi ini sangat memungkinkan untuk dikembangkan tidak hanya melalui industri dan perdagangan, tetapi juga melalui sektor pendidikan.

Sudah menjadi kewenangan daerah masing-masing untuk melakukan pengembangan potensi lokal daerah di dorong dalam kurikulum pendidikan

19 Sebagaimana disebutkan dalam Undang-Undang Nomor 23 tahun 2014 tentang Pemerintahan Daerah, yang menyebutkan bahwa urusan pemerintahan di bagi menjadi; urusan pemerintahan absolut, urusan pemerintahan konkuren, dan urusan pemerintahan umum (Pasal 9 ayat 1). Urusan pemerintahan yang dibagi antara pemerintah pusat dengan daerah provinsi dan kabupaten/kota adalah urusan konkruen (Pasal 9 ayat 3). Urusan konkruen yang menjadi kewenangan Daerah terdiri atas Urusan Pemerintahan Wajib dan Urusan Pemerintahan Pilihan (Pasal 11 ayat 1). Dan Pendidikan menjadi salah satu urusan pemerintahan wajib yang berkaitan dengan pelayanan dasar (Pasal 12 ayat 1). Sehingga pemerintah daerah dalam hal ini pemerintah provinsi atau kabupaten/kota memiliki kewenangan terkait dengan penyelenggaran Pendidikan. Termasuk di dalamnya berkaitan dengan penentuan kurikulum. Dengan tidak mengesampingkan kewenangan pemerintah pusat. 
meskipun hanya menjadi muatan lokal. Hal ini sesuai dengan apa yang disampaikan oleh Hery Trijono selaku Kepala Seksi Kurikulum Bidang Pembinaan Pendidikan Sekolah Menengah Kejuruan (SMK) Dinas Pendidikan Provinsi Jawa Timur yang biasa disapa dengan nama "Pak Hery". Beliau menyampaikan bahwa terkait dengan kurikulum di tingkat SMK, kebijakan pengembangan SMK diarahkan fokus terhadap beberapa bidang saja yaitu pertanian, kemaritiman, ekonomi kreatif dan Pariwisata. ${ }^{20}$ Pengembangan SMK juga didukung dengan Instruksi Presiden Nomor 9 Tahun 2016 tentang Revitalisasi Sekolah Menengah Kejuruan Dalam Rangka Peningkatan Kualitas dan Sumber Daya Manusia Indonesia, yang selanjutnya disebut INPRES 9/2016, yang didalamnya memerintahkan kepada para Menteri Kabinet Kerja, Kepala Badan Nasional Sertifikasi Profesi (BNSP) dan Para Gubernur dalam rangka penguatan sinergi antar pemangku kepentingan dan untuk meningkatkan kualitas dan daya saing sumber daya manusia Indonesia, maka harus memberikan perhatian secara khusus kepada beberapa hal sebagai berikut:

a. Memberikan kemudahan pada masyarakat untuk mendapatkan pelayanan pendidikan SMK yang bermutu sesuai dengan potensi wilayah masing-masing;

b. Menyediakan pendidik, tenaga kependidikan, sarana dan prasarana SMK yang memadai dan berkualitas;

c. Melakukan penataan kelembagaan SMK yang meliputi program kejuruan yang dibuka dan lokasi SMK; dan

d. Mengembangkan SMK unggulan sesuai dengan potensi wilayah masingmasing.

Untuk mendukung tercapainya INPRES 9/2016, maka perlu untuk memberikan ruang pengembangan SMK unggulan sesuai dengan potensi wilayah masing-masing. Dengan demikian, SMK di setiap kota/kabupaten bisa mengembangkan potensi daerah masing-masing terutama dalam pengembangan pertanian, kemaritiman, ekonomi kreatif dan pariwisata.

20 Wawancara dengan Hery selaku Kepala Seksi Kurikulum Bidang Pembinaan Pendidikan Sekolah Menengah Kejuruan (SMK) Dinas Pendidikan Provinsi Jawa Timur pada 5 September 2018 di Kantor Dinas Pendidikan Provinsi Jawa Timur 
Menurut Hery setiap tahun lulusan kurang lebih 200.000 siswa lulus SMP. ${ }^{21}$ Gubernur Jawa Timur membuat suatu kebijakan pemerataan okupasi tingkat pendidikan menengah atas. Adapun kebijakan Gubernur Jawa Timur adalah dengan mengarahkan siswa lulusan SMP untuk masuk SMA dibatasi $30 \%$ sedangkan sisanya 70\% diarahkan untuk masuk SMK. Dengan besarnya presentase siswa SMK, maka kurikulum yang ada di SMK harus memuat beberapa hal sebagai berikut:

a. Materi yang bersifat teknis dimana siswa SMK dipersiapkan untuk menghadapi dunia kerja;

b. Materi umum dimana siswa juga disiapkan untuk dapat menjutkan pendidikan (kuliah);

c. Materi kewirausahaan dimana siswa dipersiapkan untuk menjadi wirausahawan dan mampu bersaing dengan orang lain dalam membuka usaha.

Kebijakan Pemerintah di bidang pendidikan saat ini memberikan perhatian khusus bagi pendidikan SMK agar dapat mencetak lulusan yang berdaya saing. Oleh karena itu, perlu kurikulum yang dapat mencapai tujuan tersebut. Setiap SMK memiliki keunggulan dan karaketristik masing-masing apabila ditinjau dari potensi lokal yang ada. Tidak dapat di pungkiri bahwa sesuai dengan Peraturan Gubernur Nomor 19 Tahun 2014 tentang Mata Pelajaran Bahasa Daerah Sebagai Muatan Lokal Wajib di Sekolah/Madrasah memang hanya Bahasa Daerah yang masuk menjadi muatan lokal wajib. Akan tetapi, Hery mengutarakan "kekhasan daerah" dapat masuk di dalam muatan lokal tambahan jika memang hal tersebut dibutuhkan terutama diterapkan di sekolah dasar, SMP, dan SMA. ${ }^{22}$ Namun, untuk tingkat SMK dimungkinkan sekali mengacu pada INPRES 9/2016 dimana potensi lokal menjadi unggulan SMK. Tidak hanya itu Undang-Undang Nomor 20 Tahun 2003 tentang Sistem Pendidikan Nasional antara lain berisi pesan bahwa kurikulum memperhatikan keragaman potensi daerah dan lingkungan (vide Pasal

\footnotetext{
Id.

Id.
} 
36 ayat (3) huruf d). Ketentuan tersebut memberikan ruang bagi potensi lokal menjadi bagian dari kurikulum yang diajarkan kepada siswa.

Pemerintah Provinsi melalui Dinas Pendidikan Provinsi Jawa Timur juga mendorong kepada SMK melakukan kerjasama agar anak-anak yang lulus SMK bisa langsung dapat bekerja sebagai contoh kerjasama dengan perusahaan otomotif Honda khususnya anak-anak teknik mesin. Pada jurusan agribisnis, siswa diberikan pelatihan berulang-ulang dalam memproduksi makanan minuman kemasan sehingga layak untuk dijual. Tidak hanya itu Dinas Pendidikan Provinsi Jawa Timur juga rutin menggelar lomba untuk anak-anak SMK terkait dengan produk unggulan sekolahnya.

Bagi anak-anak di pondok pun mendapatkan perhatian yang sama oleh Dinas Pendidikan Provinsi Jawa Timur, biasa di sebut sebagai "SMK Mini”. "SMK Mini” juga ada di Madura yang salah satunya mengajarkan/melakukan pelatihan masyarakat disekitar pondok untuk menjahit. Alat-alat yang mendukung penyelenggaraan pelatihan kepada siswa dibiayai oleh pemerintah. Hal ini selaras dengan ketentuan dalam Pasal 41 ayat (1) Peraturan Daerah Provinsi Jawa Timur Nomor 9 Tahun 2014 Tentang Penyelenggaraan Pendidikan, yang selanjutnya disebut PERDA JATIM 9/2014, menyebutkan:

(1) Pemerintah Provinsi mendukung dan memfasilitasi pengembangan Balai Latihan Kerja atau Sekolah Menengah Kejuruan Mini di pondok pesantren untuk menyiapkan tenaga kerja terampil tingkat menengah;

(2) Dukungan dan fasilitasi sebagaimana dimaksud pada ayat (1) meliputi:
a. penyediaan sarana dan prasarana;
b. bantuan tenaga profesional;
c. dukungan pendanaan.

Hery menuturkan muatan lokal yang substansinya memuat kekhasan daerah sangat memungkinkan diberlakukan. ${ }^{23}$ Untuk tingkat SMA dilingkup Jawa Timur telah diterapkan, sedangkan untuk SMK dapat ditemui di SMK Unggulan. ${ }^{24}$

\footnotetext{
Id.
}

24 Id. 
Untuk pendidikan dasar menjadi kewenangan dinas pendidikan kabupaten, tetapi tetap mensinkronkan dengan kebijakan provinsi. Hery juga menyinggung bagaimana pelaksanaan SMK di Madura. Madura memiliki potensi daerah yang besar dengan lahan pertanian yang luas serta di kelilingi oleh laut. Potensi ini sangat memungkinkan jika dikembangkan oleh para lulusan SMK. Namun, karena saat ini sudah memasuki revolusi industri 4.0, pendidikan juga harus mampu menaklukkan tantangan ini. Kurikulum pendidikan harus diarahkan pada pengembangan teknologi.

Menurut Hery, ada beberapa kendala terkait dengan penerapan kurikulum berbasis potensi lokal di Madura adalah adanya persepsi negatif masyarakat dan keengganan masyarakat Madura jika diterapkan dengan teknologi. Oleh karena itu, untuk membuka jurusan baru di Madura cukup sulit. Kabupaten Sumenep menjadi salah satu kabupaten yang menjadi perhatian dari Dinas Pendidikan Provinsi Jawa Timur. Kendala yang muncul yang sifatnya lebih kepada diri perseorangan. Hal tersebut seharusnya tidak ada karena mengembangkan potensi lokal daerah adalah salah satu cara melestarikan ciri khas daerah. Hal tersebut menjadi suatu hal yang baik apabila bisa di elaborasikan dalam pendidikan.

Hasil lapangan kemudian disinkronkan dengan kondisi pendidikan di Sumenep khususnya terkait dengan penerapan muatan lokal pada jenjang pendidikan sekolah dasar (SD dan SMP). Menurut Abd. Kadir selaku Kasi Kurikulum dan Penilaian Sekolah Dasar pada Dinas Pendidikan Kabupaten Sumenep menuturkan penerapan kurikulum muatan lokal memang saat ini hanya sesuai dengan PERDA Kabupaten Sumenep dan PERGUB JATIM yaitu bahasa daerah, dalam hal ini adalah "bahasa Madura". ${ }^{25}$ Jikapun ada tambahan yaitu berupa baca-tulis Al-quran yang sesui dengan peraturan Bupati Sumenep dan itu dilaksanakan pada tingkat SD maupun SMP. Untuk Madrasah mengikuti arahan dari Kementerian Agama.

25 Wawancara dengan Abd. Kadir selaku Kepala Seksi Kurikulum dan Penilaian Sekolah Dasar pada Dinas Pendidikan Kabupaten Sumenep tanggal 23 Agustus 2018 di Kantor Dinas Pendidikan Kabupaten Sumenep. 
Terkait dengan potensi lokal Madura khususnya Sumenep, Abd. Kadir pun menegaskan bahwa banyak sekali potensi daerah Sumenep yang sangat bisa dikembangkan terutama jika itu di masukkan dalam muatan lokal. ${ }^{26}$ Namun, memang bukan suatu hal yang mudah karena diperlukan sebuah regulasi baik itu dengan PERDA Kaupaten Sumenep maupun PERBUP SUMENEP untuk mengubah kurikulum dan juga menyipakan buku ajar serta tenaga pendidik termasuk sarana prasarana pendukung.

Paling tepat dalam menerapkan kurikulum muatan lokal potensi daerah memang pada jenjang pendidikan SMA khususnya SMK yang memang secara spesifik nanti dipersiapkan untuk bekerja. Namun, memungkinkan jika memang ingin diperkenalkan terlebih dahulu pada jenjang SD maupun SMP. Dengan demikian, akan ada jenjang pemahaman terkait dengan potensi lokal Madura khususnya Sumenep. Salah satu potensi lokal ini adalah jagung. Apabila potensi lokal di bidang pertanian jagung dapat diperkenalkan terlebih dahulu sebagai ciri khas masyarakat Madura melalui kelas "bahasa Madura" yang di dalamnya membahas tentang jagung. Akan lebih baik dan efektif bila buku ajar bahasa madura siswa SD diberikan bab tersendiri tentang pengenalan jagung. Hal tersebut akan berlanjut pada jenjang SMP. Pada jenjang sekolah dasar masih pada tahap pengenalan, jika sudah memasuki SMA/SMK khususnya pada tataran praktek seperti budidaya hingga pengolahan dan distribusi dengan adanya sinkronisasi dengan perkembangan teknologi.

Dengan memasukkan kurikulum muatan lokal dnegan obyek jagung tidak hanya mengenai bagaimana menanam jagung saja, tetapi juga menumbuhkan kesadaran kepada anak-anak bahwa jagung ini merupakan sumber daya genetik lokal Madura yang harus dilestarikan. Selain itu, jagung tidak hanya sebagai bahan pokok, tetapi juga memiliki nilai ekonomis karena olahan jagung sangat variatif. Hal ini sangat mungkin dikerjakan oleh siswa-siswa SMK khususnya jurusan pertanian (agribisnis).

26 Id. 


\section{Muatan Lokal yang bisa di ajarkan terkait dengan potensi lokal “Jagung” di Sumenep.}

Jagung sebagai salah satu potensi andalan di Madura khususnya Kabupaten Sumenep, maka produksi jagung perlu ditingkatkan baik varietas jagung hibrida dan jagung lokal yang merupakan ciri khas Madura. Tidak hanya dimulai pada saat penanaman, pemanenan, pengolahan dan pemasaran, tetapi lebih dini yaitu pengenalan jagung lokal madura

Berkurangnya para petani jagung, keengganan meneruskan bertani jagung kepada keluarganya (anaknya) menjadi kendala terbesar, yang pada akhirnya akan menyebakan keengganan pula pada anak untuk meneruskan usaha orang tuanya. Jagung yang semula menjadi potensi lokal bisa saja dikemudian hari akan sangat sedikit yang mengenalnya. Kondisi inipun pernah dialami oleh Nusa Tenggara Timur yang terkenal akan "kayu cendananya", sebagai salah satu ciri khas daerah, kayu cendana ini menjadi sedikit terlupakan dan mulai sulit untuk ditemukan.

Langkah yang kemudian diambil oleh Pemerintah Provinsi adalah memasukkan materi kayu cendana tersebut dalam muatan lokal. Dimulai dari proses pembuatan aneka olahan kayu cendana (hiasan) hingga kayu cendana dipasarkan. Mengelaborasikan antara dia bidang seperti ini sangat mungkin untuk dilakukan. Salah satu capaian dari penelitian ini adalah melestarikan potensi lokal Madura dalam hal ini jagung sebagai salah satu materi muatan lokal di sekolah. Meskipun nantinya tetap ada perbedaannya pada tingkat dasar dan menengah.

Siswa sekolah dasar perlu untuk diberi pemahaman tentang kekhasan daerah Madura bukan hanya soal bahasa, tetapi juga pada sektor pertanian khususnya jagung. Sekalipun belum dapat dibentuk dalam sebuah kurikulum tersendiri karena sesuai dengan PERDA Kabupaten Sumenep maupun PERGUB JAWA TIMUR bahwa hanya bahasa daerah yang menjadi materi muatan lokal Jawa Timur. Sebagaimana saran dari Abd. Kadir bahwa pendidikan jagung bisa dimasukkan dalam materi bahasa daerah. ${ }^{27}$ Dibuatkan sebuah buku ajar bahasa

27 Id 
daerah yang di dalamnya membahas tentang jagung sebagai salah satu makanan pokok masyarakat Madura, cara bercocok tanam jagung, cara memanen dan olahan yang mungkin dapat dihasilkan dari jagung (hanya sebagai bahan tambahan dalam bahasa daerah).

Pada pendidikan SMP bisa dimasukkan dalam kegiatan ekstrakulikuler, yang biasanya diisi dengan olahraga, bermusik, bisa didalamnya diberikan materi pertanian khususnya jagung. Materi ini tentunya lebuh meningkat jika di bandingkan SD yang hanya pada tahap pengenalan. Hal ini juga diperlukan perhatian khusus dari Dinas Pendidikan Kabupaten Sumenep serta Dinas Pertanian, Tanaman Pangan, Hortikultura, dan Perkebunan Kabupaten Sumenep karena perlunya tenaga pendidik yang juga paham terkait dengan pertanian jagung. Jika di tingkat SMA atau di SMK lebih memungkinkan lagi untuk penerapan kurikulum muatan lokal berbasis kekhasan daerah dan membuka jurusan teknologi pertanian karena salah satu tujuannya adalah pengembangan sumber daya manusia. Apabila diperlukan dibentuk SMK unggulan sesuai dengan keunggulan daerah.

Kurikulum di SMK juga memungkinkan karena lebih pada tataran praktek. Sesuai dengan yang disampaikan oleh Bapak Hery bahwa siswa SMK khususnya pertanian, tidah hanya diajarkan bagimanan menanam jagung, tetapi juga bagaimana pasca panennya antara lain mengolah menjadi aneka olahan dari bahan baku jagung hingga memiliki nilai ekonomis (agribisnis) karena tujuan pendidikan SMK mencetak lulusan yang siap kerja, siap melanjutkan di pendidikan tinggi dan siap untuk mejadi wirausahawan. ${ }^{28}$ Jika diterapkan di Sumenep perlu dilengkapi dengan pembahasan tentang kegiatan inovasi di bidang pengolahan, kegiatan pasca panen berupa pengolahan produk jagung dan materi pemasaran hasil olahan sesuai dengan masukan Bagas Praptomo. ${ }^{29}$

28 Wawancara dengan Hery selaku Kepala Seksi Kurikulum Bidang Pembinaan Pendidikan Sekolah Menengah Kejuruan (SMK) Dinas Pendidikan Provinsi Jawa Timur pada 5 September 2018 di Kantor Dinas Pendidikan Provinsi Jawa Timur

29 Wawancara dengan Bagas Praptomo selaku Kepala Bidang Pengelolaan dan Pemasaran pada Dinas Pertanian, Tanaman Pangan, dan Holtikultura Kabupaten Sumenep pada 10 Agustus 2018 di Kantor Dinas Pertanian, Tanaman Pangan, dan Holtikultura Kabupaten Sumenep. 
Untuk mewujudkan gagasan pembentukan kurikulum muatan lokal terkait budidaya dan agribisnis jagung di Kabupaten Sumenep, maka diperlukan instrumen hukum pendukung berupa dibuatnya peraturan daerah kabupaten untuk tingkat SMP dan peraturan daerah provinsi Jawa Tiimur untuk tingkat SMK, sebagai dasar hukum untuk membentuk kurikulum muatan lokal terkait dengan budidaya dan agribisnis jagung. Dengan adanya peraturan daerah Kabupaten Sumenep dan peraturan daerah provinsi Jawa Timur gagasan pembentukan kurikulum muatan lokal budidaya dan agribisnis jagung dapat diwujudkan.

\section{Penutup}

Dimasukkannya potensi lokal suatu daerah dalam kurikulum muatan lokal sangat dimungkinkan, terutama pada pendidikan tingkat atas khususnya di SMK karena SMK mengajarkan keilmuan yang bersifat aplikatif. Dalam penyusunan kurikulum muatan lokal mengenai budidaya dan agrbisnis jagung ditingkat SMK tersebut perlu adanya sinergisitas antara Dinas Pendidikan Provinsi Jawa Timur dengan Dinas Pertanian Provinsi Jawa Timur. Apabila tidak dapat masuk dalam kurikulum muatan lokal wajib, dapat menjadi kurikulum muatan lokal tambahan. Apalagi jika melihat komoditas jagung masuk dalam salah satu kategori jurusan di SMK, yaitu pertanian. Namun yang perlu diperhatikan bahwa materi muatan lokal jagung ini, harus dapat menjawab tantangan revolusi industri 4.0 sehingga bukan hanya diajarkan bagaimana menanam jagung, tetapi juga bagaimana membuat olahan jagung. Sedangkan pada jenjang pendidikan dasar, penggenalan jagung bisa digabungkan dengan materi muatan lokal bahasa daerah sehingga perlu disusun buku ajar bahasa daerah yang di dalamnya membahas tentang jagung, siswa diperkenalkan dan di pahamkan bahwasanya jagung merupakan salah satu potensi lokal Madura yang perlu untuk dilestarikan.

Dengan demikian, untuk mewujudkan adanya muatan lokal mengenai jagung madura dalam kurikulum muatan lokal setiap jenjang pendidikan, maka perlu dibuatkan payung hukum berupa peraturan daerah Provinsi Jawa Timur untuk jenjang SMA/SMK, dan peraturan daerah Kabupaten untuk jenjang SD hingga SMP khususnya di Kabupaten Sumenep. Aturan hukum tersebut juga 
didukung dengan instrumen pembelajaran berupa buku ajar dan modul praktikum yang materinya tidak hanya tentang bertani saja, tetapi juga tentang pengembangan produk jagung menjadi bahan olahan yang lebih memiliki nilai tambah.

\section{Daftar Pustaka}

\section{Buku:}

Departemen Pendidikan Nasional, Model Mata Pelajaran Muatan Lokal SD/MI/SDLB-SMP/MTs/ SMPLB-MA/MA/SMALB/SMK.Jakarta: Balitbang Depdiknas, 2006.

Budi Winarno, Kebijakan Publik Teori dan Proses, Media Pressindo, Yogyakarta, 2005.

Hartiwiningsih, Lego Karjoko dan Soehartono, Metode Penelitian Hukum, Universitas Terbuka, Banten, 2019.

Ni'Matul Huda, Otonomi Daerah, Filosof, Sejarah Perkembangan dan Problematika, Pustaka Pelajar, Yogyakarta, 2005.

RDH. Koesoemaatmadja, , Pengantar ke Arah Sistem Pemerintahan Daerah di Indonesia, Bina Cipta, Bandung, 1979.

Subarsono, Analisis Kebijakan Publik: Konsep, Teori dan Aplikasi, Pustaka Pelajar, Yogyakarta, 2006.

\section{Jurnal Imiah}

Al Musanna, Revitalisasi Kurikulum Muatan Lokal Untuk Pendidikan Karakter Melalui Evaluasi Responsif, Jurnal Pendidikan dan Kebudayaan, Vol. 16, Edisi Khusus III, Oktober 2010.

Ratna Dewi, Kebijakan Pendidikan Di Tinjau Dari Segi Hukum Kebijakan Publik, Jurnal Ilmu Hukum, Volume 7, Nomor 2, Oktober, 2016.

Roni Rustandi, Kajian Teoritis Fungsi Pemerintah Daerah Dan Dewan Perwakilan Rakyat Daerah Dalam Pembentukan Peraturan Daerah Menurut Undang Undang Nomor 23 Tahun 2014 tentang Pemerintahan Daerah Sebagaimana Telah Diubah Dengan Undang-Undang Nomor 9 Tahun 2015, Jurnal Surya Kencana Dua : Dinamika Masalah Hukum dan Keadilan, Volume 4, Nomor 1 Juli 2017. 
Sufriadi dan Sobirin Malian, Problem Kewenangan Pemerintah Daerah Dalam Pengelolaan Perguruan Tinggi, Jurnal Yudisial, Volume 12, Nomor 3, Desember, 2019

\section{Undang-Undang}

Undang - Undang Nomor 20 Tahun 2003 tentang Sistem Pendidikan Nasional, Lembaran Negara Nomor 78 Tahun 2003, Tambahan Lembaran Negara Republik Indonesia Nomor 4301.

Undang-Undang Nomor 23 tahun 2014 tentang Pemerintahan Daerah.

\section{Web Dokumen:}

https://www.kompasiana.com/ramdan69/kurikulum-pendidikan-berbasis potensi-daerah_559489027293739413cb192e. diakses 19 Juli 201

https://www.kompasiana.com/ramdan69/kurikulum-pendidikan-berbasispotensi-daerah_559489027293739413cb192e. diakses 19 Juli 2018.

http://www.teropongmadura.net/2016/12/jagung-madura.html diakses 21 Juli 2018

http://kupang.tribunnews.com/2016/07/20/kurikulum-muatan-lokal-danpotensi-daerah diakses 18 Juli 2018. 